\section{Vigor Tests to Estimate Seedling Emergence Potential and Longevity in Viola Seed Lots}

\author{
Ibrahim Demir ${ }^{1}$, Tuba Celikkol, Golge Sarıkamıs, and Ceren Eksi \\ Department of Horticulture, Faculty of Agriculture, University of Ankara, \\ 06110 Diskapı, Ankara, Turkey
}

Additional index words. pansy, storage, emergence, seed vigor, saturated salt accelerated aging, accelerated aging

\begin{abstract}
A study was made of the relationship among accelerated aging (AA), saturated salt accelerated aging (SSAA), mean germination time and second day germination percentage vigor tests, and seedling emergence and longevity storage at 5 and $25{ }^{\circ} \mathrm{C}$ for 6 and 12 months. Initial germination was above $80 \%$ for all seed lots. Seedling emergence values varied between $21 \%$ and $94 \%$ and mean emergence time between 6.5 and 11.0 days among seed lots. The SSAA test correlated with emergence better than the AA test. All combinations of SSAA temperatures $\left(41,43\right.$, and $45^{\circ} \mathrm{C}$ for $\left.72 \mathrm{~h}\right)$ were correlated to emergence $(r=$ 0.95 to $0.98, P<0.001)$ and emergence rate $(r=0.90$ to $0.94, P<0.001)$. Seed germination after 6 months of storage ranged between $21 \%$ and $98 \%$ at $5{ }^{\circ} \mathrm{C}$ and $26 \%$ and $100 \%$ at $25{ }^{\circ} \mathrm{C}$. Corresponding values were $19 \%$ and $98 \%$ and $15 \%$ and $89 \%$ after 12 months. All combinations of AA and SSAA were related to longevity of seed lots, but significance for SSAA was higher (above $P<0.01)$ than AA $(P<0.05)$. In both tests, a higher aging temperature reduced the significance level. Mean germination time and second day germination percentages also predicted seedling emergence and longevity $(P<0.05$ in all cases). Standard germination percentages were successful in predicting seedling emergence $(P<0.05)$, but with one exception failed to predict $(P>0.05)$ longevity in viola seed lots. In conclusion, although both aging tests successfully differentiated seed quality, SSAA test results better predict emergence and longevity of viola seed lots.
\end{abstract}

Viola is a popular bedding plant. The relatively high initial cost of flower seeds has led growers to use precision seeding and transplant production systems to maximize seedling stands (McDonald and Kwong, 2005). Maximum efficiency in plug production to obtain optimum seedling emergence and uniformity requires high-quality seeds. Germination tests are used to evaluate the production of normal seedlings under optimal germination conditions (Atwater, 1978; Geneve, 2008). However, these do not always reflect the emergence potential of a seed lot under greenhouse or field conditions. Conditions in the transplant production environment are also not always ideal. Such environmental conditions may also vary depending on the season of sowing in flower seeds, e.g., summer sowing for fall planting or winter sowing for spring planting. Vigor tests help determine failures in emergence and stand establishment and identify the level of physiological aging of a seed lot and its potential for the development of normal seedlings under a wide range of sowing conditions (McDonald, 1975). Tests are widely used in a number of

\footnotetext{
Received for publication 22 Sept. 2010. Accepted for publication 22 Dec. 2010.

We thank TUBITAK (The Scientific and Technological Research Council of Turkey, TOVAG-108O381) for financial support and Prof. Miller B. McDonald and Alec Reynolds for critical reading and improving the text.

${ }^{1}$ To whom reprint requests should be addressed; e-mail demir@agri.ankara.edu.tr.
}

agronomic and vegetable crops (Hampton and TeKrony, 1995), but information in flower seeds is scarce.

Accelerated aging is a well-established vigor test used for large-seeded agronomic crops (Association of Official Seed Analysts, 2009; TeKrony, 1995). In this test, seeds are subjected to high temperature $\left(41\right.$ to $\left.43{ }^{\circ} \mathrm{C}\right)$ and relative humidity $(100 \%)$ over a few days $(72 \mathrm{~h})$ to induce aging, and subsequently evaluation is done by a standard germination test. The AA test is correlated with field emergence and storage longevity of various crop seeds (Association of Official Seed Analysts, 2009; TeKrony, 1995). However, AA conditions cause a rapid increase in seed moisture in small-seeded crops because of high relative humidity $(\mathrm{RH})$ in the chamber. High RH stimulates fungal infection. High seed moisture content and storage fungi can influence aging level and variation among seed lots. To eliminate these undesired aspects of AA, Jianhua and McDonald (1996) proposed a SSAA test in which the RH of air that seeds are aged under is controlled by saturated salt solutions. They concluded that an aging environment of $41{ }^{\circ} \mathrm{C}$ for $48 \mathrm{~h}$ with $\mathrm{KCl}$ and $\mathrm{NaCl}$, which provide $87 \%$ and $76 \%$ relative humidity, respectively, best predicted seed vigor for impatiens seed lots. McDonald (1997) suggested $41^{\circ} \mathrm{C}$ for 72 -h SSAA conditions for pansy seeds. He also showed that the SSAA test was repeatable among seed testing laboratories. SSAA conditions also prevented fungal disease development during the aging period (Hyatt and Tekrony, 2008). Time to radicle protrusion and seedling size were also successfully used to rank petunia and impatiens seed lots (Dutt and Geneve, 2007). However, although such studies used the vigor tests to rank the seed lots, they did not correlate vigor test results with emergence or storage potential in flower seeds. Transplant production in viola is particularly sensitive to environmental stress conditions in the greenhouse (Carpenter and Boucher, 1991; Yoon et al., 1997). Viola seeds were described as microbiotic and may lose viability within a year (Corbineau and Côme, 1991). Therefore, vigor information regarding seedling emergence in plugs and storage potential of any viola seed lots is valuable. This was designed to evaluate the use of AA, SSAA, mean germination time vigor tests for estimating seedling emergence, and storage potential of viola seed lots.

\section{Materials and Methods}

Samples of nine seed lots of viola (Viola tricolor L.) from three cultivars (Table 1) were obtained from commercial seed companies. Five lots were Fancy F1, two lots were Delta F1, and two lots were Pense Geante. Initial seed moisture content was determined using the low temperature oven method (International Seed Testing Association, 2001). Initial laboratory germination tests were conducted on four replicates of 25 seeds each (total 100 seeds). Seeds of each replicate were placed on filter paper (Filtrak, Germany) in a petri dish $(9 \mathrm{~cm})$ with $4 \mathrm{~mL}$ of distilled water. The dishes were placed in polyethylene bags and placed in an incubator at $20^{\circ} \mathrm{C}$ in the dark. Normal seedling percentages were evaluated after $14 \mathrm{~d}$ (International Seed Testing Association, 2001). Percentage of radicle emergence on the second day of the standard germination test was determined.

For the AA test, water-jacketed aging chambers produced by a commercial company were used. Special attention was paid that the temperature range was not more than $\pm 0.1^{\circ} \mathrm{C}$ during aging. Forty milliliters of distilled water was added to each plastic aging box $(11 \times 11 \times 4 \mathrm{~cm})$ and 100 seeds were placed on a monolayer cheesecloth placed on the wire mesh tray $(10 \times 10 \times 3 \mathrm{~cm})$ inside the box (Hampton and TeKrony, 1995). Seeds were aged at 41 and $43{ }^{\circ} \mathrm{C}$ for 48 and $72 \mathrm{~h}$ using one box for each aging/time combination. The standard germination test was then conducted using normal seedling development for assessment (International Seed Testing Association, 2001).

For the SSAA test, the box was filled with $40 \mathrm{~mL}$ saturated $\mathrm{NaCl}$ solution. The seeds were evenly distributed on a monolayer cheesecloth placed on the wire mesh to prevent seeds dropping into the solution in the AA and SSAA tests. Trays were placed in self-sealed plastic bags to prevent loss of RH. SSAA was carried out at 41,43 , and $45^{\circ} \mathrm{C}$ for $72 \mathrm{~h}$. After aging, seed germination tests were conducted as described.

Seeds (four replicates of 25 seeds/lot) were sown $1 \mathrm{~cm}$ deep in peatmoss (Plantaflor-Humus, Verkaufs-GmBH, Germany) in seedling trays 
$(32 \times 20 \times 6 \mathrm{~cm})$ and placed in the incubator at $20 \pm 2{ }^{\circ} \mathrm{C}$. Light was provided at seedling level by cool fluorescent lamps $\left(72 \mu \mathrm{M} \cdot \mathrm{m}^{-1} \cdot \mathrm{s}^{-1}\right)$ for $16 \mathrm{~h}$ a day. The $\mathrm{RH}$ in the cabinet was kept over $75 \%$ to reduce evaporation from the surface. The number of emerged seedlings (unfolding cotyledons on the surface) was counted daily up to $23 \mathrm{~d}$, and normal seedling (fully developed cotyledons, without any necrotic area and missing upper soil organs) percentages were calculated.

The mean germination/emergence time (MGT/MET) was calculated using the formula:

$$
\mathrm{MGT} / \mathrm{MET}=\sum \mathrm{n} . \mathrm{t} / \sum \mathrm{n}
$$

where $n=$ number of seeds newly germinated/ emerged at time $\mathrm{t} ; \mathrm{t}=$ days from planting; and $\sum n=$ final germination/emergence.

Storage longevity was determined for 6 and 12 months. Seed moisture was adjusted to $6 \% \pm 0.5 \%$ (fresh weight basis). Four subsamples of 100 seeds from each seed lot were stored at $5^{\circ}$ and $25^{\circ} \mathrm{C}$ (two samples each) in airtight laminated aluminium foil packets. Samples were taken from the storage packets after 6 and 12 months and standard germination tests (normal seedling percentages) conducted at $20^{\circ} \mathrm{C}$ for $14 \mathrm{~d}$ in the dark.

Statistical analysis was conducted using the Statistical Package for Social Sciences (SPSS, Chicago, IL) by using analyses of variance. Mean separation was made at the $5 \%$ level by the Duncan multiple range test. Correlation coefficients $(r)$ of vigor tests with seedling emergence performance and storage longevity were also calculated.

Table 1. Cultivars, seed moisture, and seed weight of viola seed lots used in the experiment.

\begin{tabular}{|c|c|c|c|}
\hline Lot & Cultivar & $\begin{array}{c}\text { Seed } \\
\text { moisture } \\
(\%)\end{array}$ & $\begin{array}{c}\text { Seed wt } \\
(\mathrm{g} / 100 \text { seeds })\end{array}$ \\
\hline 1 & Fancy F1 hybrid & 5.5 & 0.1216 \\
\hline 2 & Fancy F1 hybrid & 5.5 & 0.1216 \\
\hline 3 & Fancy F1 hybrid & 5.5 & 0.1216 \\
\hline 4 & Fancy F1 hybrid & 5.5 & 0.1216 \\
\hline 5 & Fancy F1 hybrid & 7.6 & 0.0603 \\
\hline 6 & F1 Delta Premium & 7.6 & 0.0603 \\
\hline 7 & F1 Delta Premium & 4.5 & 0.1204 \\
\hline 8 & Pensee geante & 4.5 & 0.1204 \\
\hline 9 & Pensee geante & 8.3 & 0.1216 \\
\hline
\end{tabular}

Table 2. Standard germination percentages, mean germination time, and second day radicle germination percentages (radicle emergence) of the viola lots.

\begin{tabular}{lccc}
\hline Lot & $\begin{array}{c}\text { Initial } \\
\text { germination } \\
(\%)\end{array}$ & $\begin{array}{c}\text { Mean } \\
\text { germination } \\
\text { time (days) }\end{array}$ & $\begin{array}{c}\text { Second day } \\
\text { germination } \\
(\%)\end{array}$ \\
\hline 1 & $94 \mathrm{a}^{\mathrm{z}}$ & $3.3 \mathrm{a}$ & $70 \mathrm{~b}$ \\
2 & $98 \mathrm{a}$ & $3.3 \mathrm{a}$ & $70 \mathrm{~b}$ \\
3 & $93 \mathrm{a}$ & $3.3 \mathrm{a}$ & $75 \mathrm{~b}$ \\
4 & $98 \mathrm{a}$ & $3.6 \mathrm{a}$ & $92 \mathrm{a}$ \\
5 & $90 \mathrm{a}$ & $4.6 \mathrm{~b}$ & $29 \mathrm{~cd}$ \\
6 & $96 \mathrm{a}$ & $4.4 \mathrm{~b}$ & $36 \mathrm{c}$ \\
7 & $80 \mathrm{a}$ & $5.2 \mathrm{c}$ & $16 \mathrm{de}$ \\
8 & $88 \mathrm{a}$ & $7.0 \mathrm{~d}$ & $2 \mathrm{f}$ \\
9 & $86 \mathrm{a}$ & $6.5 \mathrm{~d}$ & $3 \mathrm{ef}$ \\
\hline
\end{tabular}

${ }^{\mathrm{z}}$ In the vertical column, any two means with a letter in common are not significantly different $(P<0.05)$.

\section{Results}

Seed moisture contents of seed lots ranged between $4.5 \%$ and $8.3 \%$, and seed weight ranged between $0.060 \mathrm{~g}$ and $0.121 \mathrm{~g} / 100$ seeds (Table 1). Initial laboratory germination values were above $80 \%$ for all seed lots. Lots 2 and 4 had $98 \%$ as a maximum and Lot 7 had a minimum of $80 \%$ (Table 2). Initial seed germination was not significant among the lots $(P>0.05)$. The fastest germinating seed lots were $1,2,3$, and 4 with a germination time of 3.3 to $3.6 \mathrm{~d}$. These were significantly faster than the rest of the lots $(P<0.05)$. Lots 5, 6, and 7 had a medium germination time. The slowest germinating lots were Lots 8 and 9 (Table 2).

Accelerated aging and SSAA results are presented in Table 3. The first four seed lots generally had the highest germination after both aging tests except in a few cases (AA $41{ }^{\circ} \mathrm{C}, 72 \mathrm{~h}$; SSAA $43{ }^{\circ} \mathrm{C}, 72 \mathrm{~h}$ ). Both tests provided a wide range of germination values after aging, and showed a good separation of vigor among the lots. Lots 5 and 6 had medium vigor and Lots 8 and 9 had the lowest vigor values. Extended aging time and higher temperatures reduced the germination percentages after aging. The extent of the reduction varied among the lots. The decline was smaller in more vigorous lots (Lots 1 to 4 ) and larger in medium (5, 6, and 7) and low (8 and 9) vigor seed lots. Aging level indicated by germination occurred less in almost all seed lots in SSAA than in AA for the same aging period and temperature. For example, Lot 1 had $63 \%$ and $81 \%$ for aging at $43{ }^{\circ} \mathrm{C}$ for $72 \mathrm{~h}$ in AA and SSAA, respectively; Lot 4 had $61 \%$ and $80 \%$; and Lot 6 had $33 \%$ and $59 \%$ (Table 3 ).

Maximum seedling emergence obtained from Lots 1 and 6 had values of between $86 \%$ and $94 \%$ (Table 4 ). Lots 8 and 9 had minimum emergence percentages of $21 \%$. The first six lots also emerged the fastest, in between 6.5 and $8.1 \mathrm{~d}$, with no significant differences between the lots $(P>0.05)$. Similar to the emergence percentages, the longest time to emergence was by Lots 8 and 9 at 10.2 and $11.0 \mathrm{~d}$, respectively (Table 4). Lots 1 and 6, Lot 7, and Lots 8 and 9 were statistically different as the highest, medium, and lowest emerging lots, respectively. Similar groupings were noted for mean germination time values.

All seed vigor tests correlated with seedling emergence and mean emergence time. However, the level of significance varied. All aging combinations of SSAA and mean germination time were highly correlated $(P<$ 0.001 ) with both seedling criteria. The AA test was significant at $P<0.01$ in all cases, but at $43{ }^{\circ} \mathrm{C}$ for $72 \mathrm{~h}$, it was $P<0.001$. Second day germination and the standard germination test also correlated with the seedling performance of the lots.

Longevity of viola seeds varied among the seed lots (Table 5). The first six lots had higher values after any storage combination. Longer seed storage periods did not cause the seed lots to have a greater reduction in germination. In particular, Lots 2, 3, and 4 had $80 \%$ even after the relatively severe storage conditions of $25^{\circ} \mathrm{C}$ for 12 months. Lots 1 ,

Table 3. Germination percentages of viola seed lots after AA and SSAA vigor tests.

\begin{tabular}{|c|c|c|c|c|c|c|c|}
\hline \multirow[b]{3}{*}{ Lot } & \multicolumn{4}{|c|}{ AA } & \multirow{2}{*}{\multicolumn{3}{|c|}{$\frac{\text { SSAA }}{72 \mathrm{~h}}$}} \\
\hline & \multicolumn{2}{|c|}{$41^{\circ} \mathrm{C}$} & \multicolumn{2}{|c|}{$43^{\circ} \mathrm{C}$} & & & \\
\hline & $48 \mathrm{~h}$ & $72 \mathrm{~h}$ & $48 \mathrm{~h}$ & $72 \mathrm{~h}$ & $41^{\circ} \mathrm{C}$ & $43^{\circ} \mathrm{C}$ & $45^{\circ} \mathrm{C}$ \\
\hline$\overline{1}$ & $97 \mathrm{a}^{\mathrm{z}}$ & $94 \mathrm{a}$ & $63 \mathrm{~b}$ & $68 \mathrm{a}$ & $95 \mathrm{a}$ & $81 \mathrm{a}$ & $88 \mathrm{a}$ \\
\hline 2 & $95 \mathrm{a}$ & $90 \mathrm{ab}$ & $75 \mathrm{a}$ & $68 \mathrm{a}$ & $96 \mathrm{a}$ & $81 \mathrm{a}$ & $86 \mathrm{a}$ \\
\hline 3 & $92 \mathrm{ab}$ & $83 \mathrm{~b}$ & $69 \mathrm{ab}$ & $69 \mathrm{a}$ & $95 \mathrm{a}$ & $70 \mathrm{a}$ & $83 \mathrm{a}$ \\
\hline 4 & $91 \mathrm{ab}$ & $95 \mathrm{a}$ & $83 \mathrm{a}$ & $61 \mathrm{ab}$ & $95 \mathrm{a}$ & $80 \mathrm{a}$ & $76 \mathrm{ab}$ \\
\hline 5 & $84 \mathrm{ab}$ & $91 \mathrm{ab}$ & $51 \mathrm{c}$ & $48 \mathrm{~b}$ & $80 \mathrm{~b}$ & $80 \mathrm{a}$ & $57 \mathrm{c}$ \\
\hline 6 & $84 \mathrm{bc}$ & $67 \mathrm{c}$ & $26 \mathrm{~d}$ & $33 \mathrm{c}$ & $86 \mathrm{ab}$ & $59 \mathrm{~b}$ & $60 \mathrm{bc}$ \\
\hline 7 & $71 \mathrm{c}$ & $47 d$ & $23 \mathrm{~d}$ & $6 \mathrm{~d}$ & $46 \mathrm{c}$ & $27 \mathrm{c}$ & $51 \mathrm{c}$ \\
\hline 8 & $15 \mathrm{~d}$ & $3 \mathrm{e}$ & $0 \mathrm{e}$ & $1 \mathrm{~d}$ & $15 \mathrm{~d}$ & $1 \mathrm{~d}$ & $9 \mathrm{~d}$ \\
\hline 9 & $11 \mathrm{~d}$ & $6 \mathrm{e}$ & $3 \mathrm{e}$ & $0 \mathrm{~d}$ & $17 \mathrm{~d}$ & $3 \mathrm{~d}$ & $4 \mathrm{~d}$ \\
\hline
\end{tabular}

${ }^{\mathrm{z}}$ In the vertical column, any two means with a letter in common are not significantly different $(P<0.05)$. $\mathrm{AA}=$ accelerated aging; SSAA = saturated salt accelerated aging.

Table 4. Seedling emergence percentages and mean emergence time of viola seed lots.

\begin{tabular}{|c|c|c|}
\hline Lot & $\begin{array}{c}\text { Seedling } \\
\text { emergence } \\
(\%)\end{array}$ & $\begin{array}{c}\text { Mean } \\
\text { emergence time } \\
\text { (days) }\end{array}$ \\
\hline$\overline{1}$ & $92 \mathrm{a}$ & $7.4 \mathrm{a}$ \\
\hline 2 & $94 \mathrm{a}$ & $7.2 \mathrm{a}$ \\
\hline 3 & $90 \mathrm{a}$ & $6.5 \mathrm{a}$ \\
\hline 4 & $86 \mathrm{a}$ & $8.1 \mathrm{a}$ \\
\hline 5 & $86 a$ & $7.6 \mathrm{a}$ \\
\hline 6 & $87 \mathrm{a}$ & $7.5 \mathrm{a}$ \\
\hline 7 & $58 \mathrm{~b}$ & $9.8 \mathrm{~b}$ \\
\hline 8 & $21 \mathrm{c}$ & $10.2 \mathrm{c}$ \\
\hline 9 & $21 \mathrm{c}$ & $11.0 \mathrm{c}$ \\
\hline
\end{tabular}

Table 5. Changes in germination percentages of viola seed lots after 6 and 12 months of storage at 5 and $25^{\circ} \mathrm{C}$.

\begin{tabular}{lccrlll}
\hline & \multirow{2}{*}{$\begin{array}{c}\text { Initial } \\
\text { germination }\end{array}$} & \multicolumn{4}{c}{ Storage } \\
\cline { 3 - 4 } Lot & percentage & $5^{\circ} \mathrm{C}$ & $25^{\circ} \mathrm{C}$ & & $5^{\circ} \mathrm{C}$ & $25^{\circ} \mathrm{C}$ \\
\hline 1 & $94 \mathrm{a}^{\mathrm{z}}$ & $76 \mathrm{a}$ & $97 \mathrm{a}$ & & $87 \mathrm{a}$ & $78 \mathrm{a}$ \\
2 & $98 \mathrm{a}$ & $98 \mathrm{a}$ & $100 \mathrm{a}$ & & $98 \mathrm{a}$ & $88 \mathrm{a}$ \\
3 & $93 \mathrm{a}$ & $94 \mathrm{a}$ & $99 \mathrm{a}$ & & $94 \mathrm{a}$ & $80 \mathrm{a}$ \\
4 & $98 \mathrm{a}$ & $95 \mathrm{a}$ & $94 \mathrm{a}$ & & $84 \mathrm{ab}$ & $80 \mathrm{a}$ \\
5 & $90 \mathrm{a}$ & $94 \mathrm{a}$ & $80 \mathrm{bc}$ & $58 \mathrm{c}$ & $89 \mathrm{a}$ \\
6 & $96 \mathrm{a}$ & $85 \mathrm{a}$ & $89 \mathrm{ab}$ & $72 \mathrm{bc}$ & $83 \mathrm{a}$ \\
7 & $80 \mathrm{a}$ & $53 \mathrm{~b}$ & $74 \mathrm{c}$ & $68 \mathrm{c}$ & $53 \mathrm{~b}$ \\
8 & $88 \mathrm{a}$ & $21 \mathrm{c}$ & $28 \mathrm{~d}$ & & $30 \mathrm{~d}$ & $15 \mathrm{c}$ \\
9 & $86 \mathrm{a}$ & $28 \mathrm{c}$ & $26 \mathrm{~d}$ & $19 \mathrm{~d}$ & $16 \mathrm{c}$ \\
\hline
\end{tabular}

${ }^{\mathrm{z}}$ In the vertical column, any two means with a letter in common are not significantly different $(P<0.05)$. 
5 , and 6 also appeared to be vigorous, but they had lower germination values at $5{ }^{\circ} \mathrm{C}$ over 12 months storage (Table 5). Lots 7, 8, and 9 were the lowest quality seed lots after 6 months storage at 5 or $25^{\circ} \mathrm{C}$; a large decline in germination values occurred in these lots. Lots 8 and 9 had an almost $60 \%$ reduction in germination compared with initial values within 6 months of storage. Correlation coefficient values between longevity and seed vigor tests for all combinations of SSAA and AA conditions were related to the longevity of viola seed lots (Table 6). The combination of $41^{\circ} \mathrm{C}$ and $48 \mathrm{~h}$ AA and $41{ }^{\circ} \mathrm{C}$ and $72 \mathrm{~h}$ SSAA was highly related to germination in all storage environments $(P<0.001)$. Higher temperature and aging period (i.e., $43{ }^{\circ} \mathrm{C}$ and $72 \mathrm{~h}$ ) reduced the $r$ values in AA. However, in SSAA, in three of four cases, correlation values were still significant at the 0.001 level (Table 6) at $43{ }^{\circ} \mathrm{C}$ and $72 \mathrm{~h}$. Mean germination time (MGT) was also related to emergence and longevity of viola seed lots and was very highly related to seedling emergence and longevity of all lots $(P<0.001)$. Although not as high as MGT, second day germination was also related to emergence and longevity potential of viola seed lots $(P<0.05$ and $P<0.01$ ) (Tables 6 and 7).

The standard germination test failed to predict storage longevity of viola seed lots in three of four cases and was only successful with seeds stored at $5{ }^{\circ} \mathrm{C}$ for 6 months $(P<0.01)$.

\section{Discussion}

The results of the present work show that AA and SSAA, MGT, and second day germination predicted seedling emergence and MET to seed storage longevity at optimum $\left(5^{\circ} \mathrm{C}\right)$ and high $\left(25^{\circ} \mathrm{C}\right)$ storage temperature for 12 months. For small seeds, SSAA provides a better vigor ranking. The SSAA test was recommended for small-seeded species such as vegetable and flower seeds (McDonald, 1997). Our results show that SSAA test conditions were very highly correlated $(P<0.001)$ with seed- ling emergence and storage longevity in 15 of 18 cases in viola (Tables 6 and 7) compared with 11 of 18 cases for AA. High fungal infection was observed in AA tests but not in the SSAA test. We did not determine the final seed moisture content after aging in each vigor test, but germination percentages after the same aging temperature and aging period of $43{ }^{\circ} \mathrm{C}$ for $72 \mathrm{~h}$ indicated that all seed lots had much lower germination after the AA test compared with SSAA. The difference between the two tests was as high as 26\% (Lot 6) (Table 3). These results suggest that seed moisture was greater in the AA test and caused greater deterioration. Jianhua and McDonald (1996) reported impatiens seed moisture content was $8.7 \%$ to $9.2 \%$ at $41{ }^{\circ} \mathrm{C}$ after $72 \mathrm{~h}$ at $75 \% \mathrm{RH}$ in SSAA. McDonald (1997) suggested that an aging environment of $41^{\circ} \mathrm{C}$ for $72 \mathrm{~h}$ under SSAA conditions be used for pansy seeds to rank seed lots. Our results confirmed the conclusion that this aging environment had very highly significant correlations $(P<0.001)$ with emergence and storage in six of six cases (Tables 6 and 7). Significant correlations were reported between SSAA results and emergence for a small-seeded crop, onion (Rodo and Marcos Filho, 2003) but not in flower seeds. In this work, we related vigor test results to seedling emergence and longevity. Reproducibility is one of the facets of the vigor test. McDonald (1997) also tested the reproducibility of the SSAA test among eight laboratories for viola. Seven of eight laboratories produced similar results. These findings indicated that standardization of the SSAA test was possible. More recent work in onion and tomato seed lots by Hyatt and Tekrony (2008) concluded that the SSAA test meets the criteria for a seed vigor test for small-seeded crops and flower seeds. Relative humidity in the chamber in SSAA can be controlled by various saturated solutions such as $\mathrm{NaBr}(55 \%$ $\mathrm{RH}), \mathrm{NaCl}(75 \% \mathrm{RH})$, and $\mathrm{KNO}_{3}(88 \% \mathrm{RH})$ (Hyatt and Tekrony, 2008; Jianhua and McDonald, 1996). In this work, $\mathrm{NaCl}$ was preferred because it is less expensive to use for a large number of seed lots, gives more consistent $\mathrm{RH}$ over a wide range of temperatures ( 0 to $50{ }^{\circ} \mathrm{C}$ ) (Copeland and McDonald, 1995), and provides more consistent results (McDonald, 1997).

The viola seed lots in this work derived from three different cultivars (Table 1). Seven of them were F1 hybrids and two were open-pollinated. Their genetic constitution is different. Seed lots were bought from different companies, and their production procedures are likely to vary. Genetic constitution and production procedures are considered as basic tenets of vigor differences (Hampton and TeKrony, 1995).

Fast emergence and well-developed seedlings are important to a glasshouse area and save energy and reduce workload in bedding plants (Alderson, 1987). Late emergence and non-uniform seedling development reduce the overall market value. Valuable hybrid seed use makes it necessary to obtain one plant from each module. As a result, vigor information regarding seedling emergence potential of any seed lot has great value for transplant purposes. This work demonstrates that the AA and SSAA tests predicted the seedling emergence potential of viola seed lots. The results are in agreement with previous studies on tomato and onion seeds that both tests can be successfully used for ranking the lots (Hyatt and Tekrony, 2008). However, estimating emergence potential in viola under various environmental sowing conditions may have value (Côme, 1991). Because viola seeds are sown in summer (high temperature), or at the end of winter (cool temperature) for transplant production for fall and spring outdoor plantings, seed vigor determinations are important. In this work, Lots 8 and 9 had lighter seeds (Table 1) and their emergence percentages were poorer than those of others. Lighter seeds may have smaller or not any embryos (Agnieszka and Holubowicz, 2008). Smaller seeds also take up water more rapidly resulting in increased aging. Lot 7 also had inferior emergence percentages but had the same seed
Table 6. Correlation coefficient values $(r)$ between vigor tests and germination after 6 and 12 months of storage at 5 and $25^{\circ} \mathrm{C}$ in viola seed lots.

\begin{tabular}{|c|c|c|c|c|}
\hline \multirow[b]{3}{*}{ Vigor tests } & \multicolumn{4}{|c|}{ Storage period } \\
\hline & \multicolumn{2}{|c|}{6 months } & \multicolumn{2}{|c|}{12 months } \\
\hline & $5^{\circ} \mathrm{C}$ & $25^{\circ} \mathrm{C}$ & $5^{\circ} \mathrm{C}$ & $25^{\circ} \mathrm{C}$ \\
\hline \multicolumn{5}{|l|}{$\mathrm{AA}$} \\
\hline $41^{\circ} \mathrm{C} / 48 \mathrm{~h}$ & $0.93 * * *$ & $0.99 * * *$ & $0.94 * * *$ & $0.97 * * *$ \\
\hline $41^{\circ} \mathrm{C} / 72 \mathrm{~h}$ & $0.96 * * *$ & $0.95 * * *$ & $0.88^{* *}$ & $0.97 * * *$ \\
\hline $43^{\circ} \mathrm{C} / 48 \mathrm{~h}$ & $0.88 * *$ & $0.87 * *$ & $0.87 * *$ & $0.83 * *$ \\
\hline $41^{\circ} \mathrm{C} / 72 \mathrm{~h}$ & $0.89^{* *}$ & $0.77^{*}$ & $0.87 * *$ & $0.86^{* *}$ \\
\hline \multicolumn{5}{|l|}{ SSAA } \\
\hline $41^{\circ} \mathrm{C} / 72 \mathrm{~h}$ & $0.96 * * *$ & $0.94 * * *$ & $0.92 * * *$ & $0.96 * * *$ \\
\hline $43^{\circ} \mathrm{C} / 72 \mathrm{~h}$ & $0.96 * * *$ & $0.86^{* *}$ & $0.85^{* *}$ & $0.96^{* * *}$ \\
\hline $45^{\circ} \mathrm{C} / 72 \mathrm{~h}$ & $0.89 * *$ & $0.97 * * *$ & $0.98 * * *$ & $0.91 * * *$ \\
\hline SG & $0.71 * *$ & 0.62 & 0.61 & 0.65 \\
\hline MGT & $0.92 * * *$ & $0.98 * * *$ & $0.94 * * *$ & $0.93 * * *$ \\
\hline $\begin{array}{l}\text { Second day } \\
\text { germination }\end{array}$ & $0.81 * *$ & $0.86 * *$ & $0.80 * *$ & $0.80 * *$ \\
\hline
\end{tabular}

Significance: $* P<0.05, * * P<0.01, * * * P<0.001$.

$\mathrm{AA}=$ accelerated aging; SSAA $=$ saturated salt accelerated aging; MGT $=$ mean germination time.
Table 7. Correlation coefficient values $(r)$ between vigor tests and seedling emergence and mean emergence time in viola seed lots.

\begin{tabular}{|c|c|c|}
\hline Vigor tests & $\begin{array}{c}\text { Seedling } \\
\text { emergence }(\%)\end{array}$ & $\begin{array}{l}\text { Mean emergence } \\
\text { time (days) }\end{array}$ \\
\hline \multicolumn{3}{|l|}{$\overline{\mathrm{AA}}$} \\
\hline $41^{\circ} \mathrm{C} / 48 \mathrm{~h}$ & $0.98 * * *$ & $0.90 * *$ \\
\hline $41^{\circ} \mathrm{C} / 72 \mathrm{~h}$ & $0.97 * * *$ & $0.90 * *$ \\
\hline $43^{\circ} \mathrm{C} / 48 \mathrm{~h}$ & $0.86^{* *} *$ & $0.81 * *$ \\
\hline $43^{\circ} \mathrm{C} / 72 \mathrm{~h}$ & $0.90^{* * *}$ & $0.92 * * *$ \\
\hline \multicolumn{3}{|l|}{ SSAA } \\
\hline $41^{\circ} \mathrm{C} / 72 \mathrm{~h}$ & $0.99 * * *$ & $0.95 * * *$ \\
\hline $43^{\circ} \mathrm{C} / 72 \mathrm{~h}$ & $0.97 * * *$ & $0.92 * * *$ \\
\hline $45^{\circ} \mathrm{C} / 72 \mathrm{~h}$ & $0.96 * * *$ & $0.90 * * *$ \\
\hline SG & $0.68^{*}$ & $0.73^{*}$ \\
\hline MGT (days) & $0.96^{* * *}$ & $0.90^{* * *}$ \\
\hline $\begin{array}{l}\text { Second day } \\
\text { germination }\end{array}$ & $0.82 * *$ & $0.79 *$ \\
\hline
\end{tabular}

Significance: $* P<0.05, * * P<0.01, * * * P<0.001$ $\mathrm{AA}=$ accelerated aging; $\mathrm{SSAA}=$ saturated salt accelerated aging; MGT = mean germination time. 
size as the other lots, which shows that seed vigor differences matter rather than size. Viola flowers had seed-producing ability throughout the long flowering period. Repeated pollination during that period increased seed numbers in a capsule. Some late-pollinated ovules may have produced smaller seed (Miyajima, 2006).

Corbineau and Côme (1991) described viola seeds as short-lived (microbiotic). They reported that viola seeds lose viability within 1 to 2 years. This indicates that seeds are likely to lose their viability and vigor over one production season, particularly in an uncontrolled subtropical environment. Over 12 months, some seed lots retained a reasonably high level of viability even under a poor storage temperature of $25^{\circ} \mathrm{C}$ (Table 5). In some cases, storage at $25{ }^{\circ} \mathrm{C}$ gave a higher germination than at $5{ }^{\circ} \mathrm{C}$ (Lot 5, 12 months). This may have resulted from release of dormancy in less mature seeds through after-ripening (Copeland and McDonald, 1995). However, germination percentages may not always correlate with seedling emergence. It is known that loss in seed vigor precedes the loss in viability, which means that although seeds have high germination, their vigor is likely to be reduced after storage. We did not examine seed vigor after storage, but 7-d germination percentages (not presented) were reduced compared with initial germination percentages. This indicates that extended seed germination time is necessary as seeds age. This also implies that when carryover seeds, particularly those after storage in subtropical conditions, are used for seedling production, they may have less developed seedlings.

Mean germination time and second day germination were related to seedling emergence and germination after storage. Earlier studies on various crop seeds such as maize (Matthews and Khajeh-Hosseini, 2006) and cucurbits (Mavi et al., 2010) indicated that time to germination relates to seedling emergence in modules and field. Relationship between mean germination time and seedling size was reported by Dutt and Geneve (2007) and Oakley et al. (2004) in impatiens and petunia. Dell'aquila (1987) suggested that the first sign of seed aging is time to radicle protrusion in wheat. A similar conclusion was reported by Ellis and Roberts (1980) in onion seeds. Matthews and Khajeh-Hosseini (2006) showed that as seeds age, they require a longer time to protrude a radicle, a period they named as the quiescent period between imbibition and radicle appearance, which is known as the lag period. Determining seed vigor on the basis of a germination test may be advantageous, because it is a simple, routine test that does not need additional expertise or technical knowledge. It is easily reproducible and the second day germination provides a quick and fast evaluation (Tables 6 and 7). Mean germination time in contrast involves counting radical emergence throughout the germination and necessitates more intensive workload. Second day germination is simple, fast, and uncomplicated. Further research is required using a larger number of seed lots.

In conclusion, although different tests were successful, the SSAA test was related to seedling emergence and seed longevity in viola seed lots. An aging regime of $41{ }^{\circ} \mathrm{C}$ for $72 \mathrm{~h}$ was considered best $(P<0.001)$. SSAA, AA, MGT, and second day germination tests were potentially valuable in vigor testing of viola seeds.

\section{Literature Cited}

Agnieszka, R. and R. Holubowicz. 2008. Effect of pansy (Viola $\times$ wittrockiana gams) seeds color and size on their germination. Bot. Hort. Agrobot. Cluj. 36:47-50

Alderson, P.G. 1987. Seed technology aspects of flower seed germination. Acta Hort. 202:3547.

Association of Official Seed Analysts. 2009. Baalbaki, R., S. Elias, J. Marcos-Filho and M.B. McDonald (eds.). Seed vigor testing handbook. Contribution 32. AOSA, Ithaca, NY.

Atwater, B.R. 1978. Dealing with stop-go germination in flower seeds. Acta Hort. 83:175-179.

Carpenter, W.J. and J.F. Boucher. 1991. Proper environment improves the storage of primed pansy seed. HortScience 26:1483-1485.

Côme, D. 1991. Biological basis of the use of cold in ornamental horticulture. Acta Hort. 298:2128.

Copeland, L.O. and M.B. McDonald. 1995. Principles of seed science and technology. Chapman and Hall, New York, NY.

Corbineau, F. and D. Côme. 1991. Seeds of ornamental plants and their storage. Acta Hort. 298: 313-321.

Dell'aquila, A. 1987. Mean germination time as a monitor of the seed aging. Plant Physiol. Biochem. 25:761-768.
Dutt, M. and R.L. Geneve. 2007. Time to radical protrusion does not correlate with early seedling growth in individual seeds of impatiens and petunia. J. Amer. Soc. Hort. Sci. 132:423-428.

Ellis, R.H. and E.H. Roberts. 1980. Towards a rational basis for testing seed quality, p. 605-635. In: Hebblethwaite, P.D. (ed.). Seed production, Butterworths, London, UK

Geneve, R.L. 2008. Vigor testing in small-seeded horticultural crops. Acta Hort. 782:77-82.

Hampton, J.G. and D.M. TeKrony (eds.). 1995. Handbook of vigour test methods. The Int. Seed Testing Assn., Zurich, Switzerland.

Hyatt, J.E. and D.M. Tekrony. 2008. Factors influencing the saturated salt accelerated aging test in tomato and onion. Seed Sci. Technol. 36: 534-545.

International Seed Testing Association. 2001. Rules. Seed Sci. Technol. Suppl. 29:1-131.

Jianhua, Z. and M.B. McDonald. 1996. The saturated salt accelerated aging tests for smallseeded crops. Seed Sci. Technol. 25:123-131.

Matthews, S. and M. Khajeh-Hosseini. 2006. Mean germination time as an indicator of emergence performance in soil of seed lots of maize (Zea mays). Seed Sci. Technol. 34:339-347.

Mavi, K., I. Demir, and S. Matthews. 2010. Mean germination time estimates the relative emergence of seed lots of three cucurbit crops under stress conditions. Seed Sci. Technol. 38 : 14-25.

McDonald, M.B. 1975. A review and evaluation of seed vigor tests. Proceedings of the Association of Official Seed Analysts. 65:108-139.

McDonald, M.B. 1997. The saturated salt accelerated aging test of pansy and impatiens seeds. Seed Technol. 19:103-109.

McDonald, M.B. and F.Y. Kwong. 2005. Flower seeds: Biology and technology. CABI Publishing, Cambridge, MA.

Miyajima, D. 2006. Pollination and seed production in Viola. HortScience 41:633-639.

Oakley, K., S.T. Kester, and R.L. Geneve. 2004 Computer-aided digital image analysis of seedling size and growth rate for assessing vigor in Impatiens. Seed Sci. Technol. 32:907-915.

Rodo, A.B. and J. Marcos Filho. 2003. Accelerated ageing and controlled deterioration for the determination the physiological potential of onion seeds. Sci. Agricola. 60:465-469.

TeKrony, D.M. 1995. Accelerated ageing, p. 5373. In: Van DeVenter, H.A. (ed.). Proc. Seed Testing Seminar. International Seed Testing Association, Zurich, Switzerland.

Yoon, B., H.J. Lang, and B.G. Cobb. 1997. Priming with salt solutions improves germination of pansy seed at high temperatures. HortScience 32:248-250. 